\title{
KECERNAAN BAHAN KERING DAN BAHAN ORGANIK IN VITRO DAUN MAJA (Aegle marmelos) DAN DAUN GAMAL (Gliricidia sepium)
}

Digestibility of Dry Matter and Organic Matter in vitro Aegle marmelos and Gliricidia sepium Leaves

\author{
Harniati*, Rohmiyatul Islamiyati**, Ismartoyo** \\ *)Alumni Fakultas Peternakan Universitas Hasanuddin \\ **)Staf Pengajar Fakultas Peternakan - Universitas Hasanuddin \\ Jl. Perintis Kemerdekaan Km. 10 Tamalenrea Makassar. \\ email:islamiyati@unhas.ac.id.
}

\begin{abstract}
ABSTRAK
Tujuan penelitian ini adalah untuk mengetahui kecernaan bahan kering dan bahan organik in vitro daun maja (Aegle marmelos) dan daun gamal (Gliricidia sepium). Penelitian ini dianalisis menggunakan uji T dengan lima ulangan. Data hasil penelitian menunjukkan bahwa kecernaan bahan kering dan bahan organik in vitro tidak berbeda nyata $(\mathrm{P}>0,05)$ antara daun maja dan daun gamal. Disimpulkan bahwa kecernaan bahan kering dan bahan organik in vitro daun maja dan daun gamal adalah sama
\end{abstract}

Kata kunci : Daun maja, daun gamal, kecernaan, in vitro

\section{PENDAHULUAN}

Gamal (Gliricidia sepium) merupakan tanaman leguminosa yang memiliki kandungan protein cukup tinggi, daun gamal ini banyak di manfaatkan di antaranya pakan ternak ruminansia. Sebaliknya daun maja (Aegle marmelos) kurang dimanfaatkan oleh peternak sebagai pakan ternak, padahal tanaman ini juga memiliki kandungan protein yang tinggi. Maka dari itu pada penlitian ini akan membandingkan nilai kecernaan daun gamal dan daun maja.

Daun maja (Aegle marmelos) memiliki kandungan nutrisi seperti kadar air 10,07\%, protein kasar 18,20\%, lemak kasar 3,84\%, serat kasar 16,16\% dan kadar abu 23,18\% (Singh dkk, 2012). Adapun zat anti nutrisi pada daun maja (Aegle marmelos) yaitu tannin $2,3 \%$ saponin $3,7 \%$ dan phytic 0,6 (Harniati 2018). Sedangkan kandungan nutrisi yang terkandng pada daun gamal (Gliricidia sepium) yaitu kadar protein $25,7 \%$, serat kasar 13,3\%, kadar abu 8,4\% dan BETN 4,0\%(Hartadi et al, 1997)

Metode in vitro adalah suatu metode pendugaan kecernaan secara tidak langsung yang dilakukan di laboratorium dengan meniru proses yang terjadi di dalam saluran pencernaan ruminansia. Keuntungan metode in vitro adalah waktu lebih singkat dan biaya lebih murah. Metode in vitro bersama dengan analisis kimia saling menunjang dalam membuat evaluasi pakan hijauan (Pell dkk, 1993).

Kecernaan bahan kering dipengaruhi oleh kandungan protein pakan, karena setiap sumber protein memiliki kelarutan dan ketahanan degradasi yang berbeda-beda. Kecernaan 
bahan organik merupakan faktor penting yang dapat menentukan nilai pakan. Setiap jenis ternak ruminansia memiliki mikroba rumen dengan kemampuan yang berbeda-beda dalam mendegradasi ransum, sehingga mengakibatkan perbedaan kecernaan (Sutardi dkk, 2001).

\section{MATERI DAN METODE PENELITIAN}

\section{Materi Penelitian}

Bahan yang digunakan dalam penelitian ini adalah daun maja (Aegle marmelos), daun gamal (Gliricidia sepium), dan cairan rumen. Peralatan yang digunakan adalah blender, termos, dan alat-alat laboratorium untuk analisis bahan kering dan bahan organik in vitro

\section{Metode Penelitian}

Persiapan sampel daun maja dan daun gamal. Hijauan dipilih dalam keadaan segar dan diambil bagian yang dapat dikonsumsi oleh ternak. Hijauan ditimbang, setelah itu bahan dioven dengan suhu $60^{\circ} \mathrm{C}$ sampai kering, digiling lalu diayak melalui saringan berdiameter $1 \mathrm{~mm}$. Tahap kedua yaitu pengujian kecernaan bahan kering dan bahan organik in vitro dengan metode Tilley dan Terry (1963).

\section{Parameter yang Diukur}

Parameter yang diukur dalam penelitian ini adalah kecernaan in vitro bahan kering (KCBK) dan kecernaan in vitro bahan organik (KCBO) daun maja (Aegle marmelos) dan daun gamal (Gliricidia sepium.

$$
\mathrm{DCBK}=\frac{B K S-(B K R-B K R B)}{\mathrm{BKS}} \times 100 \%
$$

Keterangan :

DCBK = Daya Cerna Bahan Kering

BKS $\quad=$ Bahan Kering Sampel

BKR $\quad=$ Bahan Kering Residu

$\mathrm{BKRB}=$ Bahan Kering Residu Blanko

$$
\mathrm{DCBO}=\frac{B O S-(B O R-B O R B)}{\mathrm{BOS}} \times 100 \%
$$

Keterangan :

$\begin{array}{ll}\mathrm{DCBO} & =\text { Daya Cerna Bahan Organik } \\ \mathrm{BOS} & =\text { Bahan Organik Sampel } \\ \mathrm{BOR} & =\text { Bahan Organik Residu } \\ \mathrm{BORB} & =\text { Bahan Organik Residu } \\ & \text { Blanko }\end{array}$

\section{Analisis data}


Data yang diperoleh dalam penelitian ini menggunakan SPSS uji T (uji independen sampel T Test) (Sugiyono, 2010).

\section{HASIL DAN PEMBAHASAN}

Kecernaan bahan kering dan bahan organik daun maja (Aegle marmelos) dan daun gamal (Gliricidia sepium) pada hasil penelitian dapat dilihat pada Gambar 3 dan Gambar4.

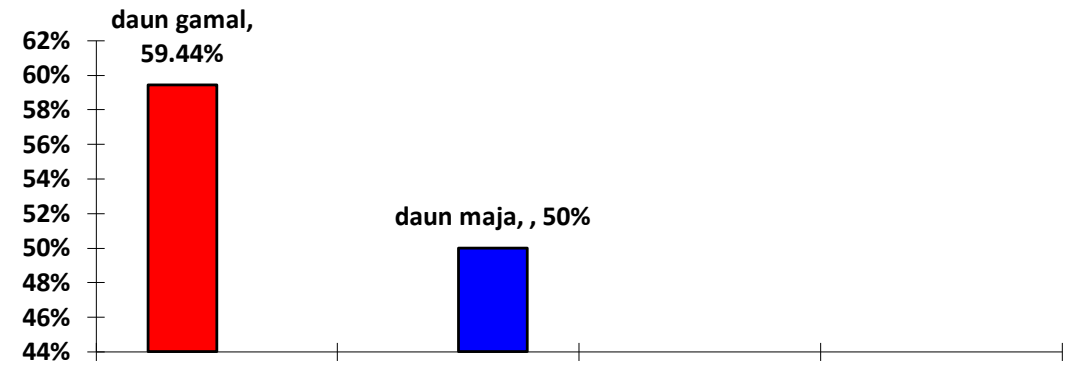

Gambar 3. Kecernaan Bahan Kering In vitro Daun Maja (Aegle marmelos) dan Daun Gamal (Gliricidia sepium).

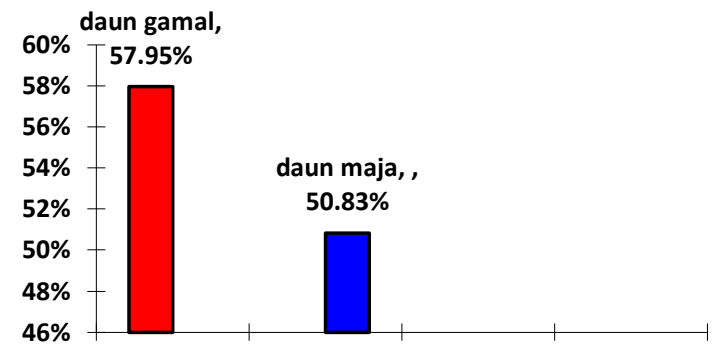

Gambar 4. Kecernaan Bahan Organik in vitro Daun Maja (Aegle marmelos) dan Daun Gamal (Gliricidia sepium)

Berdasarkan uji t bahwa kecernaan bahan kering dan bahan organik in vitro tidak berbeda nyata $(\mathrm{P}<0.05)$ antara daun maja dan daun gamal. Kecernaan bahan kering daun gamal ( $59,44 \%)$ dan kecernaan bahan kering daun maja (50\%). Kecernaan bahan organik daun gamal $(57.95 \%)$ dan kecernaan bahan organik daun maja $(50.83 \%)$. Hal ini menunjukkan bahwa tingginya kecernaan bahan kering pakan juga diikuti oleh kecernaan bahan organik. Sutardi, dkk (2001) menyatakan bahwa bahan organik berkaitan erat dengan bahan kering karena bahan organik merupakan bagian terbesar dari bahan kering. Tinggi rendahnya konsumsi bahan organik akan dipengaruhi oleh tinggi rendahnya konsumsi bahan kering.

Kecernaan bahan kering dan bahan organik hasil penelitian yang didapatkan lebih rendah dibanding dengan penelitian Hadi dkk (2011) menyatakan bahwa nilai kecernaan bahan kering gamal (Gliricidia sepium) 60,06\% dan bahan organik gamal (Gliricidia sepium) 59,13\%, adanya perbedaan nilai yang didapat cenderung dipengaruhi oleh tingkat kesuburan tanaman, umur tanaman dan lama pakan dalam rumen. Semakin tinggi kecernaan bahan kering suatu bahan pakan semakin tinggi pula peluang nutrisi yang dapat dimanfaatkan oleh ternak untuk pertumbuhan. MCdonald 
et al,.(2002) menyatakan bahwa nilai daya cerna bahan kering dan bahan organik dapat dipengaruhi oleh komposisi bahan pakan, perlakuan pakan dan taraf pemberian pakan.

\section{Kesimpulan}

\section{KESIMPULAN DAN SARAN}

Berdasarkan penelitian yang telah dilakukan disimpulan bahwa kecernaan bahan kering dan bahan organik in vitro daun maja (Aegle marmelos) dan daun gamal (Gliricidia sepium) adalah sama.

\section{DAFTAR PUSTAKA}

Hadi. R.F., Kustantinah., H. Hartadi.(2011). Kecernaan in-sacco hijauan leguminosa dan hijauan non leguminosa dalam rumen sapi peranakan oongole. Buletin Peternakan Vol.35(2):79-85

Hartadi, H., S. Reksohadiprodjo dan A.D. Tillman. 1997. Tabel Komposisi Pakan Untuk Indonesia. Cetakan III. Gadjah Mada University Press, Yogyakarta.

McDonald, p.,r.a. Edwards, j.f.d. greenhalg and c.a. morgan. 2002. Animal nutrition. $6^{\text {th }}$ ed. Ashford color pr., gosport.

Pell., Cherney and J.S. Jones. 1993. Technical note: Forage In vitro Dry Matter Digestibility as influenced by Fibre Source in The Donor Cow Diet. J. Animal Sci 71.

Sugiyono. 2010. Metode Penelitian Pendidikan Pendekatan Kuantitatif, kualitatif, dan R\&D. Bandung: Alfabeta

Sutardi, T., N. A. Sigit, T. Toharmat. 2001. Standarisasi Mutu Protein Bahan Makanan Ruminansia Berdasarkan Parameter Metabolismenya oleh Mikroba Rumen. Fapet IPB Bekerjasama dengan Direktur Jenderal Pendidikan Tinggi. Departemen Pendidikan dan Kebudayaan. Jakarta.

Tilley, J.M. A. dan R.A. Terry, 1963. The relationship between the soluble constitutent herbage and their dry matter digestibility. J. British Feed Sci. 18:104111 